\title{
Assessing Political Risk Analysis in a Hybrid Regime: The case of Zimbabwe
}

\section{Dr Itai Makone}

Department of Political Science

Stellenbosch University, South Africa

\section{Dr Derica Lambrechts}

Department of Political Science

Stellenbosch University, South Africa

\section{DOI - https://doi.org/10.35293/srsa.v43i1.366}

\section{Abstract}

Political Risk Analysis (PRA) levels are theoretically postulated to increase in a hybrid regime. This paper argues that there is a change to this hypothesis. A single case research design was employed, using Zimbabwe from 1990 to 2018. During the period, Zimbabwe showed five diverse forms of hybridity which are liberal, competitive illiberal, competitive, illiberal, and military hybrid regimes. A conceptual framework is developed to assess political risk in a hybrid regime using hybrid regime indicators and some political risk factors of most concern to developing countries. 28 key informants from six categories of respondents were interviewed. Illegitimacy, corruption, the staleness of leadership, adverse government regulation, election violence, and severed home-host state relations were confirmed to increase the perception of political risk in a hybrid regime. Investors were observed to have developed a tolerance for some "unacceptable" factors that increased political risk. Military tutelage, weak institutions, flawed elections, military generals in power, undemocratic means to retain power, minimum horizontal accountability and weak rule of law were found to not automatically increase political risk as before. The paper concludes that there is no single form of hybridity and as such different forms of hybrid regimes accrue different levels of political risk, some lower levels while others substantially higher levels. Therefore, in a hybrid regime, a differentiated PRA monitoring, assessing and mitigation strategy will be most effective for management to implement. 
Future studies can apply the analytical framework of assessing PRA in a hybrid to another hybrid regime to expand the theoretical propositions made by this paper.

Keywords: Political Risk Analysis, Political Risk, Hybrid Regime, Risk Assessment and Mitigation 


\section{Introduction}

Assessment and mitigation of PRA for foreign investors is crucial for any political regime. The three broad political regimes identified by this paper are democracy, authoritarian regime and hybrid regime (Morlino 2009, 282; Cassani 2012, 4). A political regime is a set of procedures that identifies who has access to power; who can select the government, given specific conditions by which authority is exercised within a specific state (Kailitz 2013,39). Lower levels of political risk are traditionally attributed to states that are democratic, liberal and capitalist, while non-democracies accrue high levels of political risk (Green 1974, 35; Jarvis and Griffiths 2007,15 ). This is because democracies have institutions that constrain the executive arm of government to not advance policies unfavourable to MultiNational Companies (MNC) and leaders in a democracy can be punished at the polls and not voted into office again because they had a poor reputation with financial market and if they retract their commitments made about foreign investments. In addition, democracies offer guarantees for the protection of property rights, stable policies and there is potential for MNCs to participate in drafting policies (Jensen 2003, 592; 2008, 1050-52).

Literature postulates that there are higher levels of political risk for authoritarian regimes. The reasons proffered for this are that centralised political systems possibly headed by military dictators are seen as politically unstable and there is uncertainty over the orderly transfer of power (Robock 1971, 16; Green 1974,35). Additionally, authoritarian regimes cannot credibly commit to securing property rights and there is the potential of political instability as a result of the government's dissent on the citizens and uncertainty over the orderly transfer of power(Venter 1999, 78; Jensen 2003, 592). However, authoritarian regimes are argued to be stable for foreign (Howell and Chaddick 1994, 76). This stability should only be considered as short-term and not a guarantee for future stability (Sottilotta 2016).

A hybrid regime embodies institutions of democracy and autocracy and the regime has been present for over a decade (Diamond 2002, 23; Morlino 2009, 282). It became pronounced after the third wave of democratisation alluded to by Huntington (1991). Traditionally, a hybrid regime is hypothesised to invariably accrue high levels of political risk (Green 1974, 35; Simon 1984, 127; Jarvis and Griffiths 2007, 15). Authoritarian regimes are claimed to be more stable for 
foreign investment than the hybrid regime which is volatile (Sottilotta 2016, 72). This paper will not dispute that when political regimes are compared for political risk levels, the hybrid regime is traditionally ascribed to have a higher risk. This is attributed to the coexisting of democracy and autocracy in one political regime, which are antagonistic and have different sets of priorities.

This paper seeks to critically assess if the traditional conceptual perceptions of political risk for the hybrid regime are still applicable using a single case study of Zimbabwe from 1990 to 2018. It is because an understanding of whether the traditional perceptions of political risk are still applicable will provide more insights on how to monitor, assess and design PRA mitigation strategies for foreign investors in hybrid regimes. First, the paper conceptualises hybrid, PRA and develops an analytical framework that assesses PRA levels in Zimbabwe. Next, the research design and data collection methods are deliberated. Subsequently, Zimbabwe's hybrid development is discussed. Thereafter the findings, discussion and theoretical contribution of this paper are discussed.

\section{Hybrid Regime and PRA Conceptualisations and the Analytical Framework}

This section discusses the hybrid regime and PRA conceptualisations and develops a framework to analyse PRA in a hybrid regime.

\subsection{Hybrid Regime Conceptualisation}

The approaches by Wigell (2008) and Gilbert and Mohseni (2011) are selected to conceptualise a hybrid regime because they present a multi-dimensional approach suitable for analysis Wigell (2008) and Gilbert and Mohseni (2011). Wigell (2008) focused on democracy and liberalism which are achieved through the process of elections and constitutionalism. Gilbert and Mohseni (2011) use competition, civil liberties, and tutelary interference to analyse the hybrid regime. Similar indicators given by these aforesaid authors are merged to conceptualise the hybrid regime. The indicator of competition by Gilbert and Mohseni (2011) is similar to elections by Wigell (2008). The indicators of civil liberties and constitutionalism are similar. Wigell (2008) specifies election empowerment and election sovereignty under an additional criterion of elections which have 
similar components of what Gilbert and Mohseni (2011) refers to as tutelary interference. Therefore, the conceptualisation to be utilised by this paper will be the following: i) competition/elections renamed as elections, ii) civil liberties/ constitutionalism renamed as civil liberties, and iii) tutelary interference/election empowerment/election sovereignty renamed as tutelary interference.

Elections are multi-party, mostly regular and competitive, however, unfair competition is experienced (Gilbert and Mohseni 2011, 285). Civil liberties determine the fairness of the competition exhibited in a political regime (Gilbert and Mohseni 2011, 285). These are state- specific and contextual. Institutions that enable fair competition among political players in a hybrid regime exist, for example, the judiciary. However, unfair competition exists due to discretion applied by the institutions favouring the incumbent. Tutelary interference is when external bodies coerce elected officials to circumvent proper decisionmaking processes or lead to national legislation being circumvented (Gilbert and Mohseni 2011,286; Mufti 2018,115). Tutelage can be applied by a person, group, family or institution which could be the military, religious bodies, a monarchy, MNCs, and terrorist groups (Wigell 2008, 239).

To analyse the hybrid regime, this paper adds the indicator of political elite cohesion. Political elite cohesion analyses the unity among the key decisionmakers, it is contextual and case-specific. Political elites are important in a hybrid regime because they are the agents of more sustainable change than the bottom-up approach from the masses (Menocal et al 2008,35). Four elements denote political elite cohesion which are political elite cooperation, factionalism, prevention of threats from external actors and leadership turnover. This conceptualisation of the hybrid regime is applied to the case of Zimbabwe. Additionally, the hybrid indicators discussed will be used as inputs in the analytical framework developed by this paper.

\subsection{Political Risk and PRA Conceptualisation}

Decision-makers must consider the political risk before an initial project investment and during project implementation in a host country. Traditionally, political risk was perceived as the relationship between a host government and MNCs (Kobrin 1979, 67). This conceptualisation influenced risk factors such as confiscation, expropriation, nationalisation, coups and riots (Robock 1971,7-12; 
Bunn and Mustafaoglu 1978, 1558). Government intervention was increasingly perceived as the major political risk factor that negatively impacted foreign investment which influenced political risk conceptualisation as unwarranted government interference with business operations (Chermak 1992, 168). There was an increase in risk factors such as operational restrictions, loss of transfer freedom, breach of contract and discrimination of taxes. Traditionally, political risk is conceptualised for foreign and not domestic investors (Kobrin 1979, 71; Simon 1982, 66). Nevertheless, domestic firms are not exempted from experiencing risk factors such as riots, nationalisation, war and import restrictions (Lambrechts and Blomquist 2016, 1).

To make the traditional conceptualisation of political risk more comprehensive a few factors must be included. These factors are terrorism, cyber-attacks, extreme weather patterns and health pandemics. Terrorist attacks disrupt business operations, destroy infrastructure and occasionally involve the kidnapping of key personnel, hence, MNCs need to consider the risk of terrorism (Bremmer and Keat 2009, 10). Politically motivated terrorism has increased and it is one of the top ten political risk factors for foreign investors in developing countries (MIGA 2012, 27). Fundamental operations are linked to cyberspace, for example, communication and critical infrastructure. Cybercrime, cyber terrorism, and cyber warfare conducted by governments, organised non-state actors and individuals pose challenges to MNCs of any size. Thus, MNCs should be cognisant of this and take pro-active measures for protection.

Extreme weather patterns and health pandemics are excluded from the traditional political risk conceptualisation because they are not politically motivated. However, when an extreme weather pattern such as a cyclone occurs the costs of interrupted production, distribution, sales and travel are high (Control Risks 2019). Extreme weather patterns were forecasted as the third highest risk for 2019 (Control Risks 2019). Infectious diseases, for example, HIV/AIDS, COVID-19 pose threats to MNCs in the areas with a high disease prevalence rate. A pandemic is a possible political risk factor when the host-government affected by the pandemic has the capacity but fails to curb the spread of the disease resulting in a high prevalence rate. MNCs may be compelled to assist in mitigating the burden of the pandemic in communities where production is located.

PRA involves the assessment, forecasting and management of political risk 
(Bremmer and Keat 2009, 192; Howell 2014, 308). PRA enables management to pursue rational decision-making for companies by identifying current and possibly future political threats and opportunities in a host country (Poirier 1997, 676). This allows investors to develop strategies, rank and select the optimal solutions that solve and mitigate the risks. PRA is most effective when conducted throughout the project's implementation (Lambrechts and Blomquist 2016, 14).

This paper proposes that adverse regulatory changes, breach of contract, transfer and convertibility restrictions, expropriation, creeping expropriation, non-honouring government guarantees, and nationalisation are the political risk factors of most common concern to investors in the case of Zimbabwe (MIGA 2012, 21; 27). Terrorism and war were excluded because Zimbabwe has a low Global terrorism index (Trading Economics, 2019b) and the last war was recorded before 1980 .

These aforesaid political risk factors and those proposed by this paper will be included in the analytical framework which is discussed in the subsequent section.

\subsection{Analytical Framework for Assessing PRA in a Hybrid Regime}

This section develops the framework to assess PRA in a hybrid regime. The paper hypothesises that a hybrid regime increases PRA. Figure 1 below shows the analytical framework.

Figure 1: Analytical Framework to Assess PRA in a Hybrid Regime

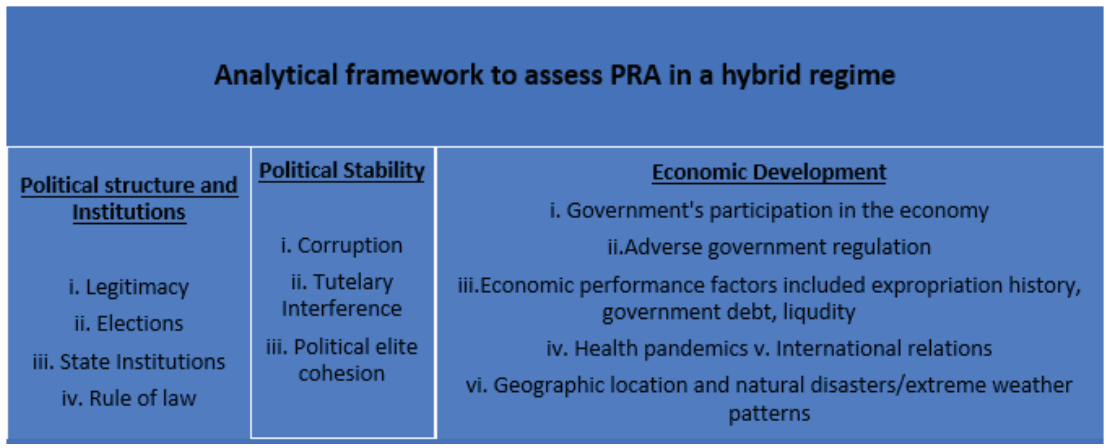

Author's compilation (2020) 
Hybrid regime indicators and political risk factors of concern to investors in developing countries are used as inputs of this analytical framework. The framework has three categories: i) political structure and political institutions, ii) political stability, and iii) economic development, as illustrated in Figure 1. Political structure and institutions examine four factors, which are elections, state institutions, rule of law and legitimacy. The second category, political stability, has three factors which were corruption, tutelary interference, and political elite cohesion. Economic development is the last category which focuses on government's participation in the economy, adverse regulations, health pandemics, extreme weather patterns, as well as the host country's economic performance and international perception by other states.

This framework will be applied to the case of Zimbabwe. The framework will not conduct a future forecast of political risk in Zimbabwe, it will analyse whether the conceptual perceptions in a hybrid regime are still applicable from 1990 to 2018. Furthermore, it will show a snapshot of the PRA levels during the period under study. The next section discusses the papers research design.

\section{Method}

A qualitative research methodology is adopted for a rich and detailed account of political risk in Zimbabwe (Parsons 2011, 407; Yin 2014, 19). A single case research-design is utilised because it allows the researcher to focus on a specific case, thereby deriving detailed and extensive information about it while retaining a holistic and real-world perspective (Yin 2014, 16). The period 1990 to 2018 was selected because the hybrid is evident from 1990, before this Zimbabwe is contextualized as an authoritarian regime. Additionally, the hybrid indicator of political elite cohesion is appropriately analysed when the incumbent party has been in government for a prolonged period. The Zimbabwe African National Union-Patriotic Front (ZANU-PF) has been the dominant political party for almost 40 years.

Data was collected using secondary data analysis and primary data. Secondary data informed the paper's literature review, developing the analytical tool and the appropriate research design and data collection methods to use. Primary data was collected between June and October 2018 using key informants because they have specialised knowledge about a concept and would give an in-depth 
description of political risk in Zimbabwe (Tremblay 1957, 689; Parsons 2011, 407). Given the sensitivity of the topic other qualitative data collection methods, for example, focus group discussions or direct observations, were not ideal. Political research is regarded with suspicion in Zimbabwe, hence meeting with respondents individually was deemed less intimidating. Also, respondents could respond openly without fear of being victimised or potentially labelled in a group. Synchronising the diaries of experts to conduct a focus group discussion on political risk in Zimbabwe would have been difficult.

A number of key informant interviews were conducted. An Ethical Clearance was obtained from Stellenbosch University before the interviews were conducted. A semi-structured interview guide was used to probe the themes raise by the respondents. Respondents participated after giving their voluntary informed consent. This paper guarantees the anonymity and confidentiality of the respondents. The respondents are referred to as for example, Academia Respondent 1. Only the respondents' contributions are discussed but anything directly identifiable to them is excluded.

A wide range of sectors should be interviewed to capture the varying perspectives and underlying issues of a problem (Tremblay 1957, 688). Six categories of respondents are selected to capture the multidimensions of political risk in Zimbabwe which are the government, the private sector, academia, embassies, civil society, and political risk companies. These categories participate by creating, measuring, reviewing, assessing, studying, or adapting to the changing levels of political risk. Purposive and snowball non-probability sampling techniques were utilised. Purposive sampling selects respondents based on their expertise of the subject matter while snowballing is when interviewed participants are asked to refer other experts the researcher can interview (Babbie 2010, 193). ATLAS.ti was used in managing the fieldwork data, however; the researcher analysed and interpreted the data using thematic analysis (Rambaree 2007, 3) 


\section{Zimbabwe Hybrid Development ${ }^{1}$}

A comprehensive conceptualisation of the hybrid regime is excluded because the main aim of this paper is to assess levels of PRA in a hybrid regime and not hybrid regime development in Zimbabwe. Zimbabwe's hybrid development is briefly discussed based on the conceptualisation of the hybrid regime, discussed in section 2.3. This paper's hybrid regime indicators are elections, civil liberties, tutelary interference, and political elite cohesion. Zimbabwe shows five diverse forms of hybridity which are liberal, competitive illiberal, competitive, illiberal, and military hybrid regimes.

From 1980 to 1990 Zimbabwe exhibited an authoritarian regime. ZANUPF dominated approximately $70 \%$ of the electoral votes which is representative of an authoritarian regime (Levitsky and Way 2002, 52). The liberal hybrid from 1990 to February 2000 is the first type. Before 1999, Zimbabwe exhibited a pluralistic media, an independent court system and growth in political parties (Chikwanha-Dzenga, Masunungure, and Madingira 1999, 6). The Movement for Democratic Change (MDC), an opposition political party founded in 1999 , drastically changed the political landscape of Zimbabwe (Mangongera 2014, 66-67), however, this change is evident in the succeeding hybrid regime. The liberal regime was thus characterised by non-competitive elections, liberal norms practised, relatively high political elite cohesion and ZANU-PF exerted tutelage.

Second, is the competitive illiberal hybrid from March 2000 to 2008. In this period MDC was highly competitive. There were five rounds of elections between 2000 and $2008^{2}$. In 2007, elections were synchronised to be conducted collectively with effect from March 2008. MDC' $s^{3}$ parliamentary margin grew from $47 \%$ in

1 A detailed explanation of the five stages of hybrid development in Zimbabwe is explained in a paper currently under review.

2 Parliamentary elections in 2000, 2005 and 2008, the presidential election in 2002 and 2008, and the local government in 2003 and 2008.

3 In 2005, MDC split into two factions known as Movement for Democratic Change-Tsvangirai (MDC-T) and Movement for Democratic Change-Mutambara (MDC-M) these factions were differentiated by the different leader's surnames. The split occurred during the senatorial elections but was caused by divisions in the executive with regards to structure, tribal issues and accountability (Moore and Raftopoulos 2012, 257). 
2000 to have the combined majority vote in parliament in 2008 (Ncube 2013, 100). Civil liberties declined due to limitations on freedom of association, speech, closing of independent media houses and the fast tract land reform programme (Mlambo 2014, 235). Politically motivated violence increased, especially in 2008 due to operation Mavhoterepi "whom did you vote for" implemented by Joint Operations Command (JOC) whose aim was to prevent a ZANU-PF presidential runoff loss in the rural areas (Mangongera 2014, 54). The period had competitive elections, was illiberal in practice, had weakening political elite cohesion and the JOC, ZANU-PF and war veterans were the informal reserves of power.

The competitive hybrid regime from 2009 to June 2013 is the third type. The major opposition MDC had the majority in parliament which compelled ZANU-PF to negotiate a coalition government with the opposition. MDC was instrumental in questioning ZANU-PF hegemony; it was a source of new ideas in parliament and there were few cases of politically motivated violence on MDC members and supporters. MDC also assisted in exposing ZANU-PF past inefficiencies, for example, the diamond and salary gate scandals, nevertheless, no ZANU-PF elite or business associates of ZANU-PF were prosecuted (Moyo 2016, 357-59). JOC exerted overt tutelary interference and the political elite cohesion within ZANU-PF was not as strong as in the 1980's period.

The illiberal hybrid from July 2013 to October 2017 is the fourth type of hybrid. ZANU-PF regained the two-thirds majority in parliament in the July 2013 harmonised elections, however, the election results were disputed by civil society, opposition parties, and the international community (Ncube 2013, 100). The judiciary was biased towards ZANU-PF (Magaisa 2019, 154). Factionalism and succession politics within ZANU-PF resulted in fragmenting its political elite cohesion. 'Lacoste' previously known as 'Weevil' led by Emmerson Mnangagwa had a fall out with a faction called 'Gamatox' lead by Joice Mujuru (Mangongera 2014, 64). This resulted in the expulsion of Mujuru as the Vice-President of ZANU-PF and was replaced by Mnangagwa in December 2014. After Mujuru was expelled, factionalism continued within ZANU-PF between Lacoste and an upcoming group called Generation Forty $(\mathrm{G}-40)$. Lacoste was more inclined to the military, war veterans and senior ZANU-PF officials while G-40 group was more inclined to educated, young and enterprising ZANU-PF officials (Mandaza and Reeler 2018, 20). The period is marked by non-competitive elections, the denying of freedoms and low ZANU-PF political elite cohesion caused by 
divisions over succession politics.

The military hybrid is the last type of hybrid regime exhibited between November 2017 and 2018. The formation of this hybrid type was catalysed by the weak ZANU-PF political elite cohesion between 2013 and 2017. The military became a formal actor in Zimbabwe's political governance. The military forced Mugabe to resign as president and endorse Emmerson Mnangagwa as president in November 2018. ZANU-PFs leadership structures from top to bottom significantly changed with more representation from the army and retired military personnel. In the July 2018 elections, ZANU-PF retained a twothirds parliamentary majority. The presidential election was highly competitive, Mnangagwa narrowly won over his major opponent Chamisa. Before the elections the environment was liberal and competition was encouraged, but after the election the political environment was repressive towards the opposition. The Zimbabwe Defence Force (ZDF) and aligned ZANU-PF elites were the two tutelage actors. The military hybrid is characterised competitive elections, a mixture of illiberal and liberal behaviour, and low political elite cohesion.

\section{Political Risk Levels in Zimbabwe}

This section discusses the conceptual perceptions of political risk in Zimbabwe from 1990 to 2018. A brief description of political risk levels in the different hybrid regimes is given, followed by the findings from applying the analytical framework to Zimbabwe. The liberal hybrid had very low political risk levels which was attributed by the regimes liberal nature (Embassy Respondent 4). Political risk levels increased during the competitive illiberal hybrid that followed because the government was intolerant to divergent views and dispensed violence on the opposition political party members (Academia Respondent 1 and 4; Embassy Respondent 4). The competitive hybrid was marked by a decrease in political risk levels due to the sincerity of parties involved in the coalition government (NGO Respondent 3). Political risk levels increased during the illiberal regime because factionalism in ZANU-PF and the government backtracked on commitments made in the preceding period (Embassy Respondent 5). The military hybrid experienced lower levels of political risk than the illiberal hybrid regime because the government was tolerant of divergent views and was motivated to attract foreign investors (MNC Respondent 3; NGO Respondent 4; Embassy 
Respondent 4).

The findings are presented according to the three categories of the analytical framework. Each indicator of the analytical framework is analysed, whether it influences changes in political risk. The findings will focus on what the majority of respondents alluded to and the relevant observations raised.

\subsection{Political Institutions and Infrastructure}

Legitimacy is measured as the wilful acceptance of the government by the citizens, that means the government exercises authority over the citizens through mutual consent and not by way of coercion (Howell and Chaddick 1994, 78). Zimbabwe was characterised as having legitimacy gaps from the year 2000 (Academia Respondent 3; Embassy Respondent 1 and 5; NGO Respondent 1). The government had occasionally used force to enforce public acceptance of it (Academia Respondent 3). The notion of Zimbabwe being an illegitimate government was described to be magnified internationally than within Zimbabwe (Academia Respondent 3; Government Respondent 4 and 5). Majority of the respondents emphasised that illegitimacy increased political risk. To emphasise this one responded said, "A country led by an illegitimate leader is a ticking time bomb. You never know when things happen; there is no stability." (Government Respondent 5). The perception of an illegitimate government in Zimbabwe had resulted in low investor confidence and low Foreign Direct Investment (FDI) inflows.

Elections were assessed as free and fair, contested or violence during an election. All respondents expressed that a free and fair election reduced political risk levels. Electoral outcomes were mainly discredited because of how the process was managed. Zimbabwe's electoral outcomes were marred by contestations between 2000 and 2018 which was echoed by majority of the respondents. Some respondents highlighted that contested elections lead to increasing political risk. On the contrary, MNCs highlighted that elections in Zimbabwe had developed a reputation of being contested, however, this did not hamper business operations as these had to continue irrespective of the electoral outcomes (MNC Respondent, 3 and 4). If election contestations led to violence occurring the associated political risk would increase. MNCs mentioned they adequately secured their premises and purchased insurance to protect themselves in the event of political 
violence occurring (MNC Respondent 1 and 5). Violence during an election was negatively perceived by a majority of respondents and leads to an increase in political risk. Investors were more concerned about election violence erupting because this could result in loss of property, disruption of operations or harm to their staff members which was highly concerning to them more than who would win the election.

The independence and strength of state institutions was assessed. Public officials are expected to be impartial, non-partisan, and not to prejudice the lawful interests of any political party. Respondents pointed out that the formal institutions in Zimbabwe were characterised as weak. The weak institutions were discussed to be associated with high levels of political risk. Respondents highlighted that the distinction between ZANU-PF and government resources, roles and duties was obscure in practise. However, when the distinction was apparent, the ZANU-PF position took precedence over government positions. MNCs showed an awareness of the ambiguity between ZANU-PF and government roles and an adaption to this behaviour (MNC Respondent 5). Potential foreign investors were also cognisant of the weak institutions, as illustrated by Government Respondent 3 in their comment:

.... if there are investors coming and they have, maybe, the protection of the president, yes, you will see them coming in and surely investing in the country. Two years down the line, their investment is affected, yes, but I think it is twosided; some may come knowing very well that their investment is going to be protected and some will just come but without the full information.

This comment shows that the practice of 'protection from the president' was a concept some investors understood and followed to operation in Zimbabwe. It is inferred that the weak institutions in Zimbabwe, coupled with the strong man leadership, resulted in having lower levels of political risk for some foreign investors.

Rule of law is when there is no bias in applying the law supported by an independent judiciary system. An inconsistent application of the law was observed between ZANU-PF elites and ordinary citizens was observed. Regarding the application of the law ZANU-PF elites and those politically connected were treated with bias than ordinary citizen (Academia Respondent 1; NGO 
Respondent 3). Rule of law was described as weak and the judiciary system as bribe-able, impacting negatively on political risk. MNCs were conscious of the lack of integrity of the law and the judiciary system. MNC Respondent 1 highlighted this in the following comment:

Now when you look at the political system, court cases can drag for long up to three or four or five years and you are looking at possibly a loss of United States Dollar (USD) 4 000-00... If it goes to court, some people have better ways to manoeuvre around the judiciary system and will get away with it, while some do not have. But all that comes back to the political environment to say, do they have the political will to say the judicial system needs to have this type of integrity? It's not there and just giving a blind eye. Company B, as big as it is, might have the muscle to say, 'We will see how it goes', but it can't be a permanent thing to say this year you have a loss of USD three million, the following year you encounter another loss of USD five million...

Investors valued rule of law; however, they had adapted to the inconsistencies of how the law was selectively and preferentially applied. Their options were either to incur the losses accrued from the judiciary system or to use informal institutions as alluded earlier as "protection from the president" or a ZANU-PF elite.

\subsection{Political Stability}

Public corruption was highlighted as high to the extent that some government ministers openly demanded $10 \%$ of the value of the project as a pre-condition to approving the project (Moyo 2016; Academia Respondent 1 and 4; Embassy Respondent 1; Embassy Respondent 5; Political Risk Company Respondent 1). The majority of respondents emphasised that a high perception of corruption led to a high perception of political risk in Zimbabwe. Despite the negative consequences of corruption, foreign investors had adjusted and learnt to budget for the "extra brown envelopes", which was referred to as "lubricating the state machinery" (Embassy Respondent 5). MNCs interviewed did not disclose if they participated in corrupt activities at any given point. It would have been difficult for them to disclose this as corruption is illegal. There were various mechanisms to fight corruption, for example, the Zimbabwe Anti-Corruption Commission 
(ZACC) but, the growth in public corruption showed that the government lacked the political will to aggressively curb corruption in the public sector.

Tutelage was observed to be exercised by ZANU-PF and the military. The impact of ZANU-PF tutelage on political risk was not clearly identified. To illustrate ZANU-PF significance, it was stated that foreign or local investors needed at least a ZANU-PF elite connection to operate in the mining, energy and petroleum sectors (Embassy Respondent 5). Military tutelage by the Zimbabwe Defence Forces (ZDF) was expressed to benefit a privileged few from the security sector. There were two contradictory opinions on the impact of military tutelage on political risk. The leading view was that military tutelage increased political risk (NGO Respondent 1, 3, and 4; Political Risk Company Respondent 1). While in the short run, a military tutelage could be perceived as stable, in the long term it was suggested to cause instability which increased political risk negatively (Political Risk Company Respondent 1).

The less dominant view was the military's involvement in politics did not influence political risk for two specific reasons (Academia Respondent 4, 5 and 6; Embassy, Respondent 5). First, it was indicated that investors operating had intimate knowledge of the military's role in politics and business. It was observed that before foreign investors officially commenced a business, they held meetings with key leaders of the military at their private residences (Embassy Respondent 5). Secondly, there was an overlap of the civil-military relations in Zimbabwe between the military and political leadership, as a result, the military's involvement in politics did not influence political risk (Academia Respondent 4). When the military was ignored politically political risk significantly increased, therefore, involving the military in the country's governance was suggested to keep political risk low (Academia Respondent 4). Most respondents underscored that after the military assisted change of government in November 2017, the perception of the associated political risk of Zimbabwe greatly diminished contrary to the expectation that it had to increase.

Political elite cohesion within ZANU-PF was assessed. Former President Mugabe led ZANU-PF for 37 years. The majority of respondents expressed that unity within ZANU-PF between 2017 and 2018 was weak compared to between 1990 and 2013. It was because ZANU-PF lacked a clear succession plan; hence different factions sought to succeed the late President Mugabe, resulting in the deterioration of political elite cohesion. One respondent mentioned that 
the minister of agriculture and the deputy minister of agriculture would take different positions on the same matter when presiding over meetings during the illiberal hybrid regime (MNC Respondent 3). Despite the negative effects of factionalism, one respondent highlighted that their organisation was surveying for possible opportunities that could arise due to the elites political fighting (MNC Respondent 5). A majority of respondents emphasised the effects of ZANU-PF elite political disintegration on the economy, they did not relate it or link to political risk. Only one respondent suggested that when the ruling party elites agreed there would be stability in the party, lowering the associated political risk because there would be predictability (Academia Respondent 5).

\subsection{Economic Development}

Government's participation in the economy was analysed using how consistent the government adheres to the developmental policies it formulates. Policy formulation and implementation by the Zimbabwean government was observed as inconsistent. Furthermore, it was highlighted by a few respondents to be a factor that affected economic risk than political risk (Academia Respondent 1; Embassy Respondent 1; Government Respondent 2 and 4). Few respondents mentioned that political risk and policy inconsistency had an inverse and indirect relationship. The casual mechanism was explained as a high positive impression caused by policy adherence resulted in positively influencing investors to be interested in investing in Zimbabwe, which in turn resulted in lowering political risk levels (Government Respondent 1, 2 and 3; MNC Respondent 3). Inconsistent policy implementation was highlighted to affect medium to long term planning of MNCs (Government Respondent 2; MNC Respondent 3 and 4).

Regarding adverse regulations, several regulations were suggested. The Indigenisation Economic and Empowerment Act (IEEA) of 2008 was the most adverse regulation followed by the Fast-Track Land Reform Programme (FTLRP). The IEEA of 2008 instructed public and private companies to restructure ownership composition to a ratio of $51 \%$ to $49 \%$ in favour of indigenous Zimbabweans (Government of Zimbabwe 2008). MNCs had to realign their ownership structure accordingly. The FTLRP expropriated land from white commercial farmers in early 2000 displacing approximately 4000 commercial 
white farmers and 450000 farm labourers (Raftopoulos 2009, 212; Mlambo 2014, 235).

The IEEA was aggressively implemented between 2009 to 2016 which negatively deterred foreign investment because of its creeping expropriation effect (Mawanza et al 2013, 78; Embassy Respondent 1, 3 and 5; Political Risk Company Respondent 1). Politicians aggressively implemented the IEEA, both as a ZANU-PF campaign strategy and motivated by the potential wealth they personally could gain. This was suggested by MNC Respondent 4 who said,

The IEEA was mainly targeting highly lucrative businesses. I think it was deliberate. People had spent time out on farms, and they saw how difficult it is to farm, so people were not keen on expropriating more farms and what have you; but they were interested in high-net-worth cash-rich businesses which were easy to run mainly, in towns....

Political elites were the ones who were strategically positioned to benefit as recipients of the $51 \%$ sale of shares of foreign businesses. Most respondents expressed that the IEEA had increased political risk levels and created uncertainty. One respondent expressed it as follows, "The general feeling was it was the second round of land reform, looting of properties and assets, people's private assets and companies- this with no compensation." The IEEA was revised removing some of the provisions during the military hybrid regime to positively encourage investment. Adverse government regulation is noted to increase political risk in Zimbabwe.

A few economic indicators that could possibly raise warning signs for foreign investors suggested by (Venter 1999, 79) were analysed. In 2016, Zimbabwe had a domestic and external debt of USD four billion and USD13 billion respectively owed (IMF 2017, 5-6). The external government debt, as a percentage of Gross Domestic Product (GDP), was above 60\% between 2009 and 2018 (Trading Economics 2019a). The current account deficit as a percentage of GDP was lowest in 2017 at $-17.45 \%$ and highest in 2018 at -1.39 between 2009 and 2018 (World Bank 2019). These economic indicators served as warning signs to investors because they showed Zimbabwe's huge debt, low savings, and a possible inability to service the debt. Zimbabwe had a history of expropriating foreign assets without compensation. The IEEA and FTLRP were selectively applied and had 
resulted in the expropriation of foreign-owned assets. Expropriation was still observed on a small and targeted basis (Political Risk Company Respondent 1). Foreign investors had to be aware that future expropriations were likely but at a minimal scale since the major expropriations of highly lucrative businesses and land had already occurred. The indicators served as warning signs to investors but could not establish the link with political risk.

The relationships between the MNC parent country and the host state were assessed. Most respondents highlighted that when there are severed home-host relationships MNCs originating from that country were exposed to higher political risk than when there are cordial relations. The MNCs originating from country three operating in Zimbabwe enjoyed favourable operating conditions throughout their existence in Zimbabwe (Embassy Respondent 3), while investors from countries one and four were negatively affected by the land reform and the IEEA (Embassy Respondent 1 and 4). Health pandemics were discussed to marginally increase political risk only in cases where the pandemic weakened the capacity of the state to respond. The location and nature of the outbreak were emphasised to enable tourists and MNCs to devise plans of how to insulate themselves from outbreaks (NGO Respondent 2; Political Risk Company Respondent 1). For Zimbabwe, extreme weather patterns and geographic location were considered insignificant in impacting political risk.

\section{PRA and Hybrid Regime: A Discussion}

This paper confirms that perceptions regarding illegitimacy, corruption, the staleness of leadership, adverse government regulations and severed home-host state relations between the MNC parent country and the host state still have the impact of increasing the perception of political risk in a hybrid regime (Robock 1971, 7; Fitzpatrick 1983, 249; Howell and Chaddick 1994, 76, 79-82; Venter 1999, 79; MIGA 2011, 21). Election violence was found to increase political risk, while a contested or unfair election had no impact on political risk. Low political elite cohesion was confirmed to increase the perception of political risk. The paper could not establish the impact of economic development, extreme weather patterns with respect to political risk. Health pandemics were found to minimally increase political risk, only when the pandemic severely hampered the 
state's ability to respond ${ }^{4}$.

The paper notes some contradictions to the theoretical perceptions of hybrid regimes. There was a tolerance level exhibited for military tutelage, weak institutions, relatively flawed elections (absent of violence), military generals in power, undemocratic means to retain power, minimum horizontal accountability, and weak rule of law. These factors have traditionally been perceived to be warning signs that would lead to increasing political risk. The military was assumed to lack governing experience, which would be detrimental in the long term (Howell and Chaddick 1994, 76; Venter 1999, 75) hence governing by military generals was perceived to increase political risk. The findings show that investment was highly revived in Zimbabwe, even when the signs pointed to weak institutions, having military tutelage and a government installed through undemocratic means during the military hybrid regime. Although the military hybrid was short-term, investors were willing to compromise and invest in a host country with a government which was overtly co-governed by the military if certain minimum requirements were adhered to. The associated political risk of Zimbabwe during the military hybrid was lower than the preceding illiberal hybrid regime.

Weak rule of law and a partial judiciary were observed in the case of the competitive hybrid and military hybrid regime. However, these aforesaid hybrid regimes had considerably high foreign investors showing interest and some investing. Foreign investors compensated for the weak institutions and weak rule of law by using informal institutions in the form of the strongman leadership of the late President Mugabe and forming joint ventures with businesses owned or proxies of ZANU-PF elites. These measures lowered political risk and guaranteed investors of some level of protection, especially in the mining, petroleum, and energy sectors. Thus, weak institutions and a partial judiciary did not invariably always increase political risk.

This paper makes two conclusions. Firstly, the traditional conceptual perceptions of political risk in hybrid regimes are still applicable, however, they are less stringently applicable in 2018 than in the 1970s. Secondly, this paper

4 Ironically, when writing the world was battling with the COVID 19 pandemic. Zimbabwe implemented a national lockdown from the end of March 2020 with restrictions relaxed progressively. Zimbabwe's response to COVID 19 would not impact political risk levels. 
concludes that within a single hybrid state, political risk levels differ within the different types of hybrid regimes; some hybrid regimes accrue lower levels of risk, while others accrue substantially higher levels of risk. This finding disregards the theoretical proposition that hybrid regimes accrue high levels of political risk as claimed by risk Green $(1974,35)$; Simon $(1984,127)$ and Jarvis and Griffiths $(2007,15)$. Figure 2 illustrates the perception of political risk levels in the different hybrid regimes in Zimbabwe.

\section{Figure 2: Political Risk Levels illustrated in Zimbabwe's Hybrid Regime}

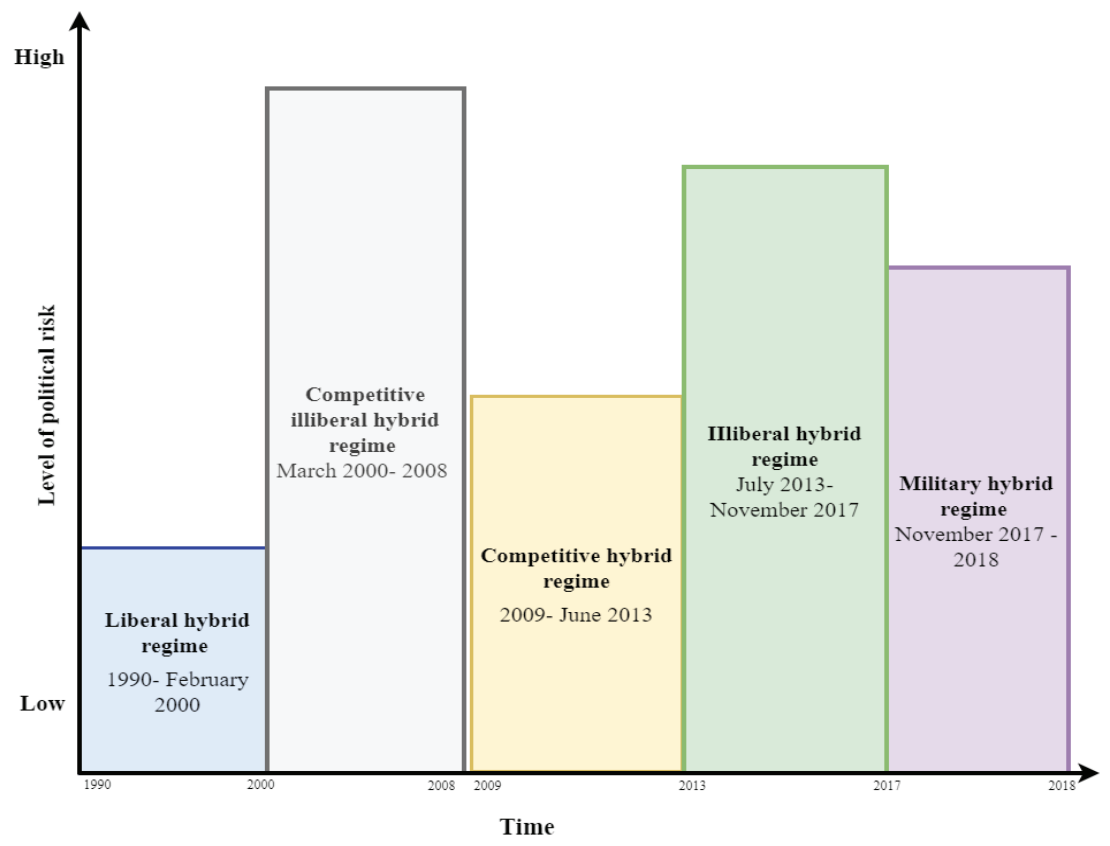

Author's compilation (2020)

The liberal hybrid was perceived to have the least political risk because of an independent and impartial judiciary, strong rule of law, high horizontal accountability, the government perceived as legitimate and strong political elite cohesion. Regardless of the uncompetitive political environment and occasional intimidation on political opponents the overall perception of risk 
was low. The competitive hybrid had the second-lowest perception of political risk. The opposition political parties formed the majority in parliament, which was the major distinction from the liberal hybrid. However, the judiciary was partial, inconsistent rule of law and average horizontal accountability made the competitive hybrid to have a higher perception of political risk than the liberal.

The military and illiberal hybrid and are numbered third and fourth respectively of investors' perceptions of perceived political risk. The military hybrid allowed political opposition more freedom, while the illiberal aggressively clamped down on an active opposition. The military hybrid was a new government, so investors probably had more confidence in the new government's ability to engage investors than the government of the late President Mugabe. The military hybrid was a short-term phenomenon; therefore possibly, after a few years, investors would regard it differently. The competitive illiberal hybrid accrued the most political risk. The competitive illiberal hybrid unleashed violence and suppressed political opponents on a larger scale. Furthermore, the IEEA and FTLRP which had an effect of expropriating foreign-owned businesses were passed in this period and changes to private property rights. Thus, investors became more risk aversive during the competitive hybrid regime.

Taking into consideration the research findings of this paper risk management and political risk analysts are better informed that:

1. Hybridity is fluid, it transitions from one form to another hence there should be constant monitoring of this regime. Moreover, the factors that are key to monitor are revealed.

2. Risk management and mitigation must have a differentiated PRA approach in the different hybrid regimes

3. This study recommends the following political risk factors as constituting moderately lower levels of political risk in a hybrid regime: competitive elections, an impartial judiciary, moderate rule of law, strong political elite cohesion of the incumbent, average horizontal accountability, election irregularities (absent of violence), an uneven non-violent political playing field, soft intimidation of political opponents, a partially active civil society and favourable government policies 


\section{Conclusion}

This paper was undertaken to provide more insights on how to monitor, assess and design PRA mitigation strategies for foreign investors in hybrid regimes. The paper sought to critically assess if the traditional conceptual perceptions of political risk for the hybrid regime were still applicable using a single case study of Zimbabwe from 1990 to 2018 (Green 1974, 35; Simon 1984, 127; Jarvis and Griffiths 2007, 15). The case of Zimbabwe shows contrary results. Zimbabwe exhibits five types of hybrid regimes these are: liberal, competitive illiberal, competitive, illiberal and the military hybrid regimes. Findings confirm that perceptions regarding illegitimacy, corruption, the staleness of leadership, adverse government regulation, election violence, and severed home-host state relations between the MNCs parent country and the host state had the impact of increasing the perception of political risk in a hybrid regime. Regarding military tutelage, weak institutions, relatively flawed elections (absent of violence), military generals in power, undemocratic means to retain power, minimum horizontal accountability and weak rule of law did not automatically increase political risk as in times past. The findings confirm that the traditional conceptual perceptions of political risk for hybrid regimes are still applicable. Furthermore, different hybrid regimes accrue different political risk levels, which contradicts the traditional hypothesis. Therefore, investors need to constantly monitor the hybrid regime and to have a differentiated approach of mitigating and managing PRA in the hybrid regime. Future studies can apply the PRA analytical framework to a different hybrid, for example, Zambia/ Rwanda (Africa), Venezuela (South America) and Turkey (Europe) to either confirm or expand on the theoretical propositions that this study made. This paper enlightens on risk monitoring, assessing and mitigation in a hybrid regime.

\section{Declaration}

This article is based on a doctoral thesis submitted at Stellenbosch University (2020), Department of Political Science, completed under the supervision of Dr Derica Lambrechts. 


\section{References}

Academia Respondent 1. 2018. Personal communication Interview, 26 June. Academia Respondent 3. 2018. Personal communication Interview, 12 July. Academia Respondent 4. 2018. Personal communication Interview, 27 June. Academia Respondent 5. 2018. Personal communication Interview, 21 August. Academia Respondent 6. 2018. Personal communication Interview, 17 August. Akkoyunlu, Feyzi Karabekir. 2014. "The Rise and Fall of the Hybrid Regime: Guardianship and Democracy in Iran and Turkey." Unpublished doctoral dissertation, The London School of Economics and Political Science.

Babbie, Earl. 2010. The Practice of Social Science Research. 12th ed. Wadsworth: Cengage Learning.

Bogaards, Matthijs. 2009. "How to Classify Hybrid Regimes? Defective Democracy and Electoral Authoritarianism." Democratization 16 (2): 399-423.

Bremmer, I. and P. Keat. 2009. The Fat Tail: The Power of Political Knowledge for Strategic Investing. New York: Oxford University Press.

Brewer, Thomas. L. 1981. "Political Risk Assessment for Foreign Direct Investment

Decisions: Better Methods for Better Results." Columbia Journal of World Business 16 (1): 5-12.

Bunn, Derek W and Mehmet M Mustafaoglu. 1978. "Forecasting Political Risk." Management Science 24 (1): 1557-67.

Cassani, Andrea. 2012. "Hybrid What? The Contemporary Debate on Hybrid Regimes and the Identity Question.” In Unpublished Paper Presented at Università Roma Tre - Facoltà Di Scienze Politiche Roma, 13-15 September, Milan. Roma: Università Roma Tre - Facoltà di Scienze Politiche.

Chermak, Janie M. 1992. "Political Risk Analysis: Past and Present." Resources Policy 18 (3): 167-78.

Chikwanha-Dzenga, Annie. Barbara, Eldred Masunungure, and Nyasha Madingira. 1999. "Democracy and the National Governance in Zimbabwe: A Country Survey Report.” Afrobarometer Paper Number 12umber 12 Cape Town: Afrobarometer Report.

Control Risks. 2019. “Top Five Risks for 2019” Control Risks. https://www. controlrisks.com/riskmap/top-five.

de la Torre, Jose and David Neckar. 1988. "Forecasting Political Risks for International Operations." Journal of Forecasting 4 (2): 221-41. 
Diamond, Larry Jay. 2002. “Thinking about Hybrid Regimes." Journal of Democracy 13 (2): 21-35.

Ekpenyong, David B and Ntiedo J Umoren. 2010. "Political Risk and the Business Environment: An Examination of Core Challenges." Journal of Financial Management \& Analysis 23 (1): 27-32.

Embassy Respondent 1. 2018. Personal communication Interview, 12 July. Embassy Respondent 3.2018. Personal communication Interview, 19 July. Embassy Respondent 4.2018. Personal communication Interview, 2 July. Embassy Respondent 5.2018. Personal communication Interview, 4 July. Fitzpatrick, Mark. 1983. "The Definition and Assessment of Political Risk in International Business: A Review of the Literature." Academy of Management Review 8 (2): 249-54.

Gilbert, Leah and Payam Mohseni. 2011. "Beyond Authoritarianism: The Conceptualization of Hybrid Regimes." Comparative International Development 46 (3): 270-97.

Government of Zimbabwe. 2008. "Indigenisation and Economic Empowerment Act." Government Gazzette. Harare: Government Gazzette.

Government Respondent 1.2018. Personal communication Interview, 7 August. Government Respondent 2. 2018. Personal communication Interview, 7 August. Government Respondent 3. 2018. Personal communication Interview, 7 August. Government Respondent 4. 2018. Personal communication Interview, 25 July. Government Respondent 5.2018. Personal communication Interview, 7 August. Green, Robert T. 1974. "Political Structures as a Predictor of Radical Change." Columbia Journal of World Business 9 (1): 28-34.

Howell, Llewellyn D. 1998. The Handbook of Country and Political Risk Analysis. 2nd ed. New York: The PRS group.

Howell, Llewellyn D. 2014. "Evaluating Political Risk Forecasting Models: What Works?” Thunderbird International Business Review 56 (4): 305-16.

Howell, Llewellyn D and Brad Chaddick. 1994. "Models of Political Risk for Foreign Investment and Trade. An Assessment of Three Approaches." The Columbia Journal of World Business 29 (3): 70-91.

Huntington, Samuel P. 1991. The Third Wave: Democratization in the Late Twentieth Century. Norman and London: University of Oklahoma Press.

International Monetary Fund (IMF). 2017. "Zimbabwe. Staff Report for the 2017 Article IV Consultation- Debt Sustainability Analysis." Washington DC: IMF. 
Jarvis, Darryl S L and Martin Griffiths. 2007. "Learning to Fly: The Evolution of Political Risk Analysis.” Global Society 21 (1): 5-21.

Jensen, Nathan. M. 2008. "Political Risk, Democratic Institution and Foreign Direct Investment." The Journal of Politics 70 (4): 1040-52.

Jensen, Nathan M. 2003. "Democratic Governance and Multinational Corporations: Political Regimes and Inflows of Foreign Direct Investment.” International Organization 57 (3): 587-616.

Kailitz, Steffen. 2013. "Classifying Political Regimes Revisited: Legitimation and Durability.' Democratization 20 (1): 39-60.

Kobrin, Stephen J. 1979. "Political Risk: A Review and Reconsideration.” Journal of International Business Studies 10 (1): 67-80.

Lambrechts, Derica and Lars B Blomquist. 2016. "Political-Security Risk in the Oil and Gas Industry: The Impact of Terrorism on Risk Management and Mitigation." Journal of Risk Research 20 (10): 1320-37.

Levitsky, Steven and Lucan Way.2002."The Rise of Competitive Authoritarianism.” Journal of Democracy 13 (2): 51-65.

Lloyd, Bruce. 1974. "The Identification and Assessment of Political Risk in the International Environment." Long Range Planning 7 (6): 24-32.

Magaisa, Alex. 2019. “Zimbabwe: An Opportunity Lost.” Journal of Democracy 30 (1): 143-57.

Mandaza, Ibbo, and Tony Reeler. 2018. "A Brief Recapitulation of the Political Events since July 2016." Harare: Southern African Political Economy Series.

Mangongera, C. 2014. “A New Twilight in Zimbabwe? The Military vs. Democracy." Journal of Democracy 25 (2): 67-76. https://doi.org/10.1353/jod.2014.0019.

Mawanza, Wilford, Nathan Mugumisi and Atanas Sixpence. 2013. "The Impact of Political Risk on the Location Decisions of Multinational Corporations: A Zimbabwean Perspective." Global Journal of Commerce and Management Perspective 2 (6): 78-84.

Moore, B., and B. Raftopoulos. 2012. "Zimbabwe's Democracy of Diminished Expectations." In Crisis! What Crisis? The Multiple Dimensions of the Zimbabwean Crisis., edited by M Chiumbu and S Musemwa, 241-67. Cape Town: Human Sciences Research Council (HSRC) Press.

Menocal, Rocha A, Verena Fritz and Lise Rakner. 2008. "Hybrid Regimes and the Challenges of Deepening and Sustaining Democracy in Developing Countries." South African Journal of International Affairs 15 (1): 29-40. https:// 
doi.org/10.1080/10220460802217934.

Multilateral Investment Guarantee Agency. 2011. "World Investment and Political Risk 2011.” Washington DC: MIGA. https://doi.org/10.1596/978-1-4648-00399.

Multilateral Investment Guarantee Agency. 2012."World Investment and Political Risk 2012." Washington DC: MIGA. https://doi.org/10.1596/978-0-8213-95080 .

Mlambo, Alois S. 2014. A History of Zimbabwe. Cambridge: Cambridge University Press.

MNC Respondent 1. 2018. Personal communication Interview, 13 July.

MNC Respondent 3. 2018. Personal communication Interview, 27 September.

MNC Respondent 4. 2018. Personal communication Interview, 2 October..

MNC Respondent 5. 2018. Personal communication Interview, 11 September.

Morlino, Leonardo. 2009. "Are There Hybrid Regimes? Or Are They Just an Optical Illusion?" European Political Science Review 1 (2): 273-96. https://doi. org/10.1017/S1755773909000198.

Moyo, Gorden. 2016. "The Curse of Military Commercialism in State Enterprises and Parastatals in Zimbabwe." Journal of Southern African Studies 42 (2): 35164. https://doi.org/10.1080/03057070.2016.1145981.

Mufti, Mariam. 2018. "What Do We Know about Hybrid Regimes after Two Decades of Scholarship?” Politics and Governance 6 (2): 112-19. https://doi. org/10.17645/pag.v6i2.1400.

Ncube, Cornelias. 2013. "The 2013 Elections in Zimbabwe: End of an Era for Human Rights." Africa Spectrum 48 (3): 99-110.

NGO Respondent 1.2018. Personal communication Interview, 23 August.

NGO Respondent 2. 2018. Personal communication Interview, 19 July.

NGO Respondent 3. 2018. Personal communication Interview, 10 July.

NGO Respondent 4. 2018. Personal communication Interview, 8 August.

Parsons, Jennifer. 2011. "Key Informant." In Encyclopedia of Survey Research Methods, edited by Paul. J Lavrakas, 406-8. Thousand Oaks: Sage publications. Poirier, Robert A. 1997. "Political Risk Analysis and Tourism." Annals of Tourism Research 24 (3): 675-80.

Political Risk Company Respondent 1.2018. Personal communication Interview, 25 October.

Raftopoulos, Brian. 2009. “The Crisis in Zimbabwe: 1998-2008." In Becoming 
Zimbabwe. A History from the Pre-Colonial Period to 2008., edited by Brian Raftopoulos and Alois. S. Mlambo, 201-33. Harare: Weaver Press.

Rambaree, Komalisingh. 2007. "Bringing Rigour in Qualitative Social Research: The Use of a CAQDAS." University of Mauritius Research Journal 13A (1): 1-16. Raftopoulos, B. 2009.“The Crisis in Zimbabwe: 1998-2008.” In Becoming Zimbabwe. A History from the Pre-Colonial Period to 2008., edited by B. Raftopoulos and A. S. Mlambo, 201-33. Harare: Weaver Press.

Robock, Stephan. 1971. "Political Risk-Identification and Assessment." Columbia Journal of World Business 6 (4): 6-20.

Sethi, Prakash S and K A N Luther.1986."Political Risk Analysis and Direct Foreign Investment: Some Problems of Definition and Measurement." California Management Review 28 (2): 57-68. https://doi.org/10.1002/tie.5060280206.

Simon, Jeffrey D. 1982. "Political Risk Assessment-Past Trends and FutureProspects." Columbia Journal of World Business 17 (3): 62-71.

Simon, Jeffrey D. 1984. "A Theoretical Perspective on Political Risk." Journal of International Business Studies 15 (3): 123-43.

Sottilotta, Cecilia. E. 2016. Rethinking Political Risk: Concepts, Theories, Challenges. 1st ed. London and New York: Routledge.

Trading Economics. 2019a. “Zimbabwe's External Debt to GDP”' 2019. https:// tradingeconomics.com/zimbabwe/government-debt-to-gdp.

Trading Economics. 2019b. “Zimbabwe Terrorism Index.” Trade Economics. 2019. https://tradingeconomics.com/zimbabwe/terrorism-index.

Tremblay, Marc A. 1957. "The Key Informant Technique: A Nonethnographic Application." American Anthropologist 4 (59): 688-701.

Venter, Albert. 1999. "The 1998 Fall of Suharto: A Vindication of Key Political Risk Indicators?” Strategic Review for Southern Africa 21 (2): 73-90.

Vukovic, Ivan. 2011."The Structure of Power in Hybrid Regimes: Institutionalized vs Personalised." In Unpublished Paper Presented at the Sixth ECPR General Conference, 26 August, Budapest.

Wigell, Mikael. 2008. "Mapping 'Hybrid Regimes ': Regime Types and Concepts in Comparative Politics." Democratization 15 (2): 230-50. https://oi. org/10.1080/13510340701846319.

World Bank. 2019. "Current Account Deficit as a Percentage of GDP” $\quad$ https://data.worldbank.org/indicator/BN.CAB.XOKA. GD.ZS?end=2017\&locations=ZW\&start=1977\&view=chart. 
Yin, Richard K. 2014. Case Study Research Design and Methods. 5th ed. Thousand Oaks, Carlifornia: Sage Publications. 